\title{
G20 and the Reform of Global Energy Governance
}

Yu Hongyuan

\begin{abstract}
Due to institutional fragmentation and conflicts among various actors, a systematic reform to improve the effectiveness of the global energy governance system has become increasingly urgent. Currently, the Group of Twenty (G20), which consists of the world's major economies and constitutes 60 percent of global energy trade, is in a good position to remold the global framework for energy governance. The past G20 summit meetings have witnessed more attention and efforts from member-state leaders to address problems associated with global energy. However, most of the discussion has been focused on technical issues rather than a comprehensive review of the whole governance system. In the future, the G20 should take proactive measures to enhance its leadership role and policy innovation in the reform of global energy governance, in order to spur green development of the world. As the largest developing nation, China should tap into the G20 platform to advance the transformation of its domestic and international energy systems.
\end{abstract}

Keywords: Energy security; global governance; green development; Group of Twenty (G20).

Yu Hongyuan is Professor and Director of the Institute of Comparative Politics and Public Policy Studies, Shanghai Institutes for International Studies (SIIS). His mailing address is 195-15 Tianlin Road, Shanghai 200233, China. He can also be reached at yuhongyuan@siis.org.cn.

(c) 2017 World Century Publishing Corporation and Shanghai Institutes for International Studies China Quarterly of International Strategic Studies, Vol. 3, No. 2, 227-242

DOI: $10.1142 / S 2377740017500142$ 
Global energy governance refers to the coordination among countries and stakeholders to cope with cross-border energy issues, the purpose of which is to maintain the stability of supply prices of energy, as well as to guarantee security of demand, so that obtainable, payable, sustainable, and efficient global energy security may be achieved. For the past few years, with the fluctuation of international oil prices, the global energy landscape has changed greatly. Despite the eastward shift of energy consumption, developing countries lack the power to establish a fair pricing mechanism in the current global energy system. With less concern over energy security of those energy-consuming countries, energy-producing countries have to resolve the dilemma between production security and market share protection. As the Trump administration begins to set obstacles to the development of renewable energy, there is an increasing demand for new reforms of global energy governance.

\section{Trudging Steps in Global Energy Governance}

The core of global governance is to exercise effective control of international affairs and actors by establishing principles, rules, norms, and institutions. ${ }^{1}$ As a significant part of global governance, energy governance has great implications for the dynamics of international relations. David Deese and Joseph Nye illustrate the effects of international energy cooperation on international security. ${ }^{2}$ Timothy Lehmann explains the latest dynamics of geopolitics under the influence of global energy in his new book. ${ }^{3}$ Mike Klare suggests that energy governance is not only the gaming result of demand and supply in the international market, but also the political arrangement of powers in the distribution of oil interest. In other words, the price of oil almost reveals the capacity of countries, and the security of energy depends on whether the oil price can be anticipated

${ }^{1}$ James N. Rosenau, "Governance in the Twenty-First Century," Global Governance, Vol. 1, No. 1 (1995), pp. 13-43.

${ }^{2}$ David Deese and Joseph Nye, eds., Energy and Security (Cambridge, Massachusetts: Ballinger Publishing, 1981).

${ }^{3}$ Timothy C. Lehmann, ed., The Geopolitics of Global Energy: The New Cost of Plenty (Boulder, Colorado: Lynne Rienner Publishers, 2017). 
and transparent. ${ }^{4}$ Daniel Yergin believes that there is only one oil market in the world and every country is just a part of it. In this vein, there is a super-large logistical system for the market, thus an oil price shock can directly affect global security status. ${ }^{5}$

Since the rules of global governance can generate winners and losers, the conflict of interests, power, and beliefs among the governors, the governed, and potential governors pose obstacles to the efficient operation of the global governance system. As a result, the construction and maintenance of global governors' position and the authority of related rules are always the core issues in global governance. Global energy governance is a complicated system with various governors who are expected to possess the authority to set agenda and establish rules. However, there has not been any united organization for energy security. The existing energy institutions, which include global institutions, regional institutions, consuming organizations, and producers' alliances, lack coordination with one another. ${ }^{6}$

Currently, there are six models for global energy governance. The first one is through international governmental organizations (IGOs), which are founded and sponsored by national governments. They have a specialized secretariat for related governance institutions. Major international organizations include the International Energy Agency (IEA), International Energy Forum (IEF), the Organization of Petroleum Exporting Countries (OPEC), the Energy Charter Treaty (ECT), the United Nations Framework Convention on Climate Change (UNFCCC), as well as other institutions of the United Nations. In addition, there are a number of organizations focusing on specific energy resources, such as the International Renewable Energy Agency (IRENA) and the International Atomic Energy Agency (IAEA). In recent years, the number of informal organizations has been increasing, such as the Clean Energy Ministerial (CEM), the Gas Exporting Countries Forum (GECF) and the International Partnership for Energy Efficiency Cooperation (IPEEC). Furthermore, there are some regional organizations, such as the

${ }^{4}$ Michael T. Klare, The Race for What's Left: The Global Scramble for the World's Last Resources (New York: Metropolitan Books, 2012), pp. 12-17.

${ }^{5}$ Daniel Yergin, “The Global Shakeout from Plunging Oil," Wall Street Journal, December 2, 2014, p. 13.

${ }^{6}$ Deborah Avant, Martha Finnemore, and Susan Sell, Who Governs the Globe? (Cambridge: Cambridge University Press, 2010), pp. 12-19. 
Association of Southeast Asian Nations (ASEAN) Energy Ministerial or the United Nations' Economic and Social Commission for Asia and the Pacific, which pay close attention to the construction of regional infrastructure.

The second governance model is through global summits. A summit meeting is similar to a leaders' club. The functions of summits, such as the Shanghai Cooperation Organization Summit, Asia-European Summit, the Group of Seven (G7) Summit, and the Group of Twenty (G20) Summit, fall in between the ones provided by the international organizations mentioned above and the ones offered by regular diplomacy of the countries. Usually, these summits have no fixed regulations or memberships, and no secretariats. Instead, they create a relatively flexible approach to address multilateral issues of common urgency.

The third model refers to international non-governmental organizations (INGOs), which do not belong to any specific country or any cause of the summits. They always have boards of functions. The fourth governance model is through multilateral financial institutions; the most famous ones are development banks. They offer economic and technological support, as well as loans, to governments in energy-related issues. The fifth governance model is through regional organizations. They have at least two member countries that seek to solve energy problems in specific fields of certain regions. The sixth model is a mixed one, containing all kinds of organizations, from transnational advocacy networks to private quasi-management institutions, global policy networks and different kinds of Point-to-Point Protocol (PPPs). All these agreements combine the former five governors with private sector entities.

It is noteworthy that this article does not consider multinational corporations as global governors unless they have joined up with other actors in partnerships or networks. Although these transnational enterprises have played an important role in oil and liberalized power markets with central and local governments, as well as with regulatory authorities, their influence has always been indirect.

The effect of global energy governance generates significant impact on the international security landscape. Compared with business interests and government policies, their concern about global governance - a political issue by nature - is secondary. 
The authority of global energy governance is always dynamic. Conflicting interests and ideas among various actors are the main reasons that the global energy governance system has no sound integration and that regular practice does not always work. The fragmentation of global governance refers to the phenomenon that several institutions coexist in a field that lacks coordination and consistency. These institutions sometimes have competing relations as they belong to different political alliances. The global energy governance system consists of a series of actors, all of whom weigh different aspects in transboundary energy policies for different purposes. With the lack of coordination among institutions, international leadership in the global energy governance system becomes increasingly important. However, such leadership that may cover the supply deficit of the global public goods is currently absent.

The traditional hegemonic governance system led by Western economies has gradually declined and finally given way to a more complicated multilevel system of global governance. On the one hand, at present, the legitimacy and credibility of the United States and the EU as the political leaders in global governance have decreased. Although the United States is still the leading economic and military power in the world, its contributions to global governance have been limited due to a series of domestic political and economic problems. Trapped in the sovereign debt crisis, refugee crisis and integration crisis (exemplified by Brexit), the EU's passion to lead global governance is also fading away, replaced by more concerns of its own survival and development. On the other hand, with growing economic power, emerging economies have acquired more material and normative power in global governance. China, for example, is capitalizing on its increasing political and economic capacity to raise its status in the world. The consequences of these changes are significant. Developed economies are trying to sidestep their responsibilities, while developing countries do not have sufficient resources and willingness to offer international public goods yet. Hence, there is no liable driver for the maintenance and reform of the global governance system.

With existing conflicts between governing efficiency and institution complications, the current system of global energy governance has encountered four major problems:

First, there is a conflict between the growing number of actors involved and the lack of united energy governance organizations. The existing 
energy institutions have increased in quantity and form. Energy has been an issue of concern for more than 20 specialized institutions of the United Nations, such as the United Nations Development Program (UNDP), the United Nations Food and Agricultural Organization (FAO), and the UNFCCC. At the same time, the United Nations Commission on Sustainable Development, the 2002 World Sustainable Development Summit in Johannesburg, and the 2012 UN Sustainable Development Summit in Rio are the coordinating platforms for mainly energy-consuming economies in the West. In addition to UN organizations, the IEA, which boasts top-class energy professional and information capacity, is the platform for energyconsuming economies, which exerts a certain level of influence in the process of global energy governance. Yet without members of emerging economies such as China and India, the representation and authority of the IEA is quite limited.

Secondly, there is a huge gap between the capacity and goals of energy institutions. The IEA, with expert groups of high efficiency, is the main energy statistical source with highest authority in the world and plays a key role in the process of global energy governance. Nevertheless, even the IEA is far from being a "global energy organization" for timely discussion or action on the most salient energy issues facing the world. Despite the rise of emerging economies, the IEA has only 34 member countries right now. As the members of IEA must be Organization for Economic Cooperation and Development (OECD) countries, it fails to include China, Russia, India, and Brazil, among others.

Founded in 1991, the IEF, an organization for dialogue in international energy, seems promising as it consists of more than 60 energy-producing countries and consumers, especially as it set up a secretariat in Riyadh in 2003, which makes the forum more internationalized. Yet the IEF does not have a solid organization structure and clear declaration of its tasks. The ECT is both an international organization with legal mandates in the energy field, and a multilateral treaty emphasizing cooperation in the energy area. The Energy Charter includes the Energy Charter Treaty, the Energy Charter Trade Clause Amendment, the Energy Efficiency and Environmental Protection Protocol, and so on. The aim of the ECT is to promote total openness in energy production, transportation and sales, which lays a foundation for the free circulation of energy, and for legal protection of foreign investment. The function of the ECT is to translate the energy rules of the World Trade 
Organization (WTO) to the trade rules of international energy and to set up a mature forum for dispute settlement in investment and transportation. However, due to the procrastination and resistance from Russia and the United States, the members are only European countries and some Central Asian countries. As a result, without a united energy-coordinating institution at the center, there remain a number of serious problems with existing energy institutions, such as ineffective governance, repetitive functions and internal conflicts. Effective global energy governance calls for more coordination among the consuming parties, represented by the IEA, the clean energy field, represented by the IRENA, and the producing parties, represented by the OPEC.

\section{Global energy}

governance

institutions require

stronger leadership

and greater

representation from

emerging energy

consumers.

Thirdly, conflicts exist between global energy governance and major energy powers' pursuit of self-interest. The United States has been the top producer in the world oil market and will remain so for the years to come. With the dollar's hegemonic position, the United States has the capacity to affect the fluctuation of the global oil price. Producing 9 million barrels of crude oil per day as of October $2014,^{7}$ the United States has successfully positioned itself as an energyproducing country. Meanwhile, the main energy institutions, such as the IEA and the New York Futures Market, are controlled by Western countries led by the United States. They affect the main investors in the financial market by releasing some key information while concealing others. In addition, the "Oil Dollar," the fact that the U.S. dollar has been practically the only currency for settling oil trade of the world, is key to the U.S. dominance of the oil price. As a result, energy has changed itself from a debt to an asset for the United States, helping to maintain the U.S. global leadership in the global energy, financial and even geopolitical arenas.

${ }^{7}$ Energy Information Administration, “U.S. Daily Average Supply and Disposition of Crude Oil and Petroleum Products (October 2014)," https://www.eia.gov/petroleum/supply/ monthly/archive/2014/2014_10/pdf/table3.pdf. 
While the prevailing realist thinking in U.S. energy diplomacy has limited the possibility of the U.S. offering more public goods in global energy governance, other countries, especially Saudi Arabia and Russia, can form some kind of constraint to the energy hegemony of the United States. For instance, OPEC, led by Saudi Arabia, is the most important force in the international oil market. Currently, OPEC countries boast 146 billion barrels of oil reservations, 77.2 percent of the world's total. Saudi Arabia alone has nearly 19.1 percent of the total reserves of the globe. ${ }^{8}$ Meanwhile, Russia has occupied an increasingly important position and strong influence in international energy production. According to the U.S. Energy Information Administration (EIA), the crude oil produced by Russia has remained at about 10 million barrels per day and its crude oil export at around 5 million barrels/day since 2004, making Russia the world's largest crude oil producer and leading exporter. ${ }^{9}$ Meanwhile, Russia has been enhancing its energy influence by pulling the Chinese and Indian markets together.

Fourthly, the shifting distribution of power in the global economic structure is creating a trend of the rising East and declining West in global energy governance. As seen in Figure 1, with the rapid increase in energy consumption caused by the fast development of emerging economies, the gravity of the global energy consuming market has shifted onto them, among which India and China top the list. By 2030, most new global energy consumption will come from those emerging economies, of which China is expected to consume 55 percent and India 18 percent. ${ }^{10}$ That will certainly give more say to both countries in global energy governance.

In short, the current global energy governance system remains decentralized and fragmented. Relevant institutions are also complicated and uncoordinated. There is still no energy institution with high representation, coordination and effectiveness. In this context, the G20, as a

${ }^{8}$ Ibid.

9 "Russia is World's Largest Producer of Crude Oil and Lease Condensate," EIA, August 6, 2015, https://www.eia.gov/todayinenergy/detail.php?id=22392; see also "Russia Crude Oil Production: 10.71M bbl/day for Feb 2017," YCharts, https://ycharts.com/indicators/russia_crude_oil_production.

10“Environment (A Special Report) — Who Wants What in Copenhagen," The Wall Street Journal, December 7, 2009, pp. 6-7. 


\section{Electricity Generation(2004-2014)}

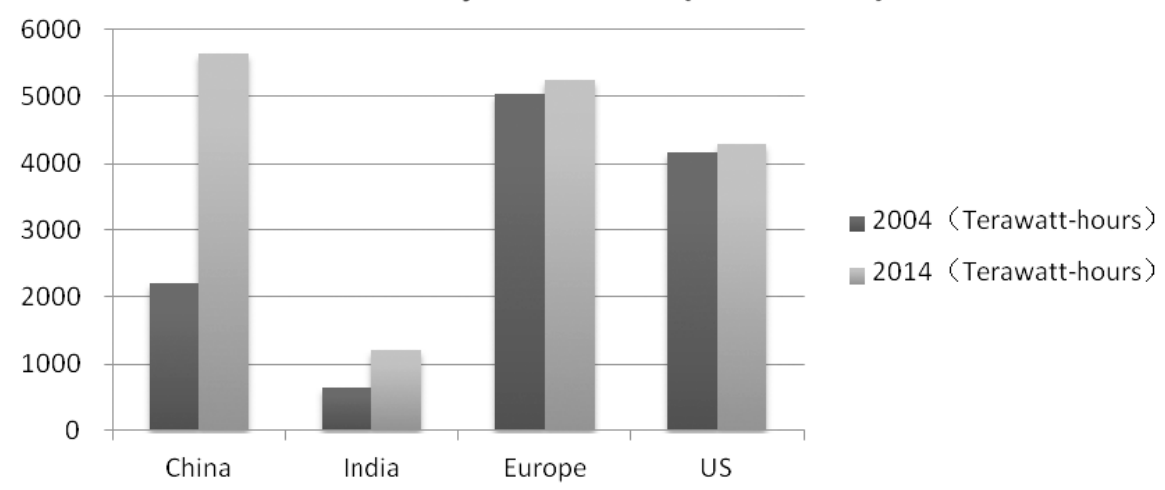

Fig. 1. Electricity Generation in China, India, Europe, and the United States.

Source: BP Statistical Review of World Energy 2015.

forum that brings together both developed and developing countries, can utilize its informal, flexible and institutional advantages to explore solutions to many energy-related issues at hand.

As Chinese President Xi Jinping mentioned at the G20 Hangzhou Summit, the G20 carries high expectations of the international community, and all participating leaders should work together to make the G20 an action team on sustainable development, green finance and energy efficiency, instead of a mere "talk shop." 11 The advantage of the G20 lies in its institutional capacity to unite major economies in the world to provide leadership in dealing with global economic issues. Therefore, there is a good foundation for G20 members to cooperate in the demand-supply coordination of energy security, as well as the strengthening of global public goods security, finance stability and climate collaboration. ${ }^{12}$ An important issue in global energy governance is how to enable the G20 to improve the authority of energy governance. For although the G20 has some programs on energy issues, most of them concentrate on technical issues rather than the political dimensions of the global energy governance system. Given that the G20 is a significant platform for global economic

11 “China Headlines: Xi Takes World's Center Stage at G20 Summit," Xinhua News, September 5, 2016, http://news.xinhuanet.com/english/2016-09/05/c_135660832.htm.

${ }^{12}$ “Xi Commends All Who Contributed to G20 Hangzhou Success," Xinhua News, September 20, 2016, http://news.xinhuanet.com/english/2016-09/20/c_135700296.htm. 
governance, it can also play a critical role in the reform of the global energy governance system.

\section{G20's Role in Global Energy Governance}

Since the 1973 Oil Crisis, the Group of Seven (G7), which consists of seven major Western countries (the United States, Japan, Germany, France, the UK, Italy, and Canada), has been dedicated to governing the international energy system by continuing the expansion of the IEA, so as to construct a globalized organization with high efficiency. Yet it has largely failed to achieve that goal due to internal conflicts of interests, the lack of an effective institution to ensure that all parties keep their promises, and its refusal to engage non-member countries in its governing process. As a result, the potential performance of the G20 has been ever more anticipated. The G20 includes members of G7, 11 important emerging economies (China, Russia, Argentina, Australia, Brazil, India, Indonesia, Mexico, Saudi Arabia, South Africa, and Turkey), and the EU. Briefly, the G20 manifests a few major features: above all, its membership covers countries from both the South and the North, the East and the West; next, fluid and informal as it is, the G20 exerts essential influence upon the existing formal international organizations; and finally, the annually rotating presidency mechanism facilitates direct participation of member countries' leaders and ministers without having to have a permanent and fixed meeting site.

In the energy field, specifically, the G20 not only consists of nearly all the major energy importers (see Figure 2), but also of key energy producers, which turn out around 70 percent of energy in the world. Besides, G20 members take up about 60 percent of global energy trade. That renders the informal coordinating mechanism a special position to play a coordinating role among different energy institutions and other international energy organizations, such as the UNFCCC, IEA, OPEC, the World Bank, the Energy Charter Secretariat, the World Meteorological Organization (WMO), and so on. As many factors - from the basic demand-and-supply structure and monopoly forces, to exchange rates of currencies and opportunistic practice in the international financial market, and to the dynamics of international geopolitics - can exacerbate the fluctuation of energy prices and bring risks to the security of global energy, the G20 also 


\section{Total Oil Import in 2015}

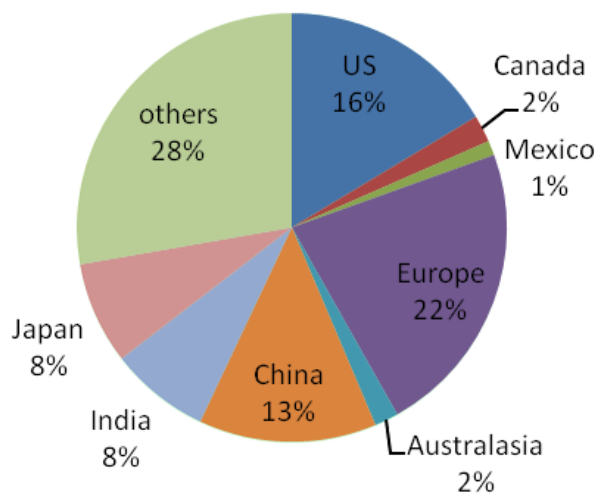

Fig. 2. G20 Members' Oil Imports in 2015.

Source: BP Statistical Review of World Energy 2015.

has an intrinsic responsibility to make comprehensive political and economic plans on energy governance.

The G20 is in the best position to promote the reform of global energy governance.

Since the G20 was upgraded in 2008 to a summit attended by the leaders of member countries in 2008, it has put much focus on energy issues and has achieved a lot of progress in global energy governance (see Table 1). Energy security was addressed at the 2008 Washington Summit, which passed an agreement to end the subsidy for fossil fuel gradually. The Seoul Summit in 2010 emphasized the importance of green development. At the Cannes Summit in 2011, G20 members set up a working group on the markets of energy and bulk commodities based on the existing institutions, and reviewed a number of reports on the influence of price fluctuations of bulk commodities on the world economy, as well as the initiative mechanism of united oil statistics, price report institutions, green growth, and energy subsidy, in order to coordinate the progress in related fields. Those issues were restated at the 2012 Los Cabos Summit, where G20 members were committed to reducing the use of fossil fuel and investing in clean energy. At the 2013 St. Petersburg Summit, the G20 established the Energy Sustainability Working Group, which was authorized to address such issues as energy efficiency, the global energy structure, market transparency and investment, and the natural gas market, among others. The Working Group 
Table 1. Major Energy Governance Issues at G20 Summits.

\begin{tabular}{|c|c|}
\hline Venue and Year of G20 Summits & Main Issue(s) of Energy Governance \\
\hline Washington, D.C., the U.S., 2008 & Addressed energy security \\
\hline Pittsburg, the U.S., 2009 & Agreed to gradually end subsidy for fossil fuel \\
\hline Seoul, South Korea, 2010 & Discussed green growth \\
\hline Cannes, France, 2011 & $\begin{array}{l}\text { Set up a working group on the markets of energy and } \\
\text { bulk commodities; reviewed reports on the initia- } \\
\text { tive mechanism of united oil statistics, price report } \\
\text { institutions, green growth, and energy subsidy }\end{array}$ \\
\hline Los Cabos, Mexico, 2012 & $\begin{array}{l}\text { Committed to the gradual elimination of inefficient } \\
\text { fossil fuel and to investing in clean energy }\end{array}$ \\
\hline St. Petersburg, Russia, 2013 & $\begin{array}{l}\text { Established an energy sustainability working group; } \\
\text { discussed sustainable energy policy and risk- } \\
\text { resistance of global bulk commodities }\end{array}$ \\
\hline Brisbane, Australia, 2014 & Agreed upon eight principles on energy cooperation \\
\hline Antalya, Turkey, 2015 & $\begin{array}{l}\text { Addressed energy poverty and sustainable } \\
\text { development }\end{array}$ \\
\hline Hangzhou, China, 2016 & $\begin{array}{l}\text { Discussed energy poverty, renewable energy, and } \\
\text { international energy governance }\end{array}$ \\
\hline
\end{tabular}

Source: Compiled by author.

was also supposed to work on the gradual elimination of inefficient fossil fuel discussed at the 2009 Pittsburg Summit.

The 2014 Brisbane Summit declared that one of the most important issues for the G20 is to promote energy cooperation, as the growth of the world economy desperately needs a strong and risk-resistant energy market. The Brisbane Summit reached eight principles on energy cooperation, among which the first three are the most important:

1. To garantee all the countries and people can get reliable and affordable energy.

2. To guarantee International Energy Agency becomes more representative, including all the emerging countries and the developing countries.

3. To encourage and promote the energy market to tend to be more healthy, open, competitive, efficient, stable, and transparent, in order to improve the trade and investment of energy ... ${ }^{13}$

To follow up, the Ministerial of the 2016 Hangzhou Summit passed the Beijing Bulletin, the main document, and three attached documents,

13“The G20 Global Infrastructure Initiative,” https://g20.org.tr/wp-content/uploads/ 2014/12/g20_note_global_infrastructure_initiative_hub.pdf. 
reaching six key consensuses, including the pledge to "expand the area of energy popularity from the Sub-Saharan Africa to the Asian-Pacific region with 500 million electricity-unavailable people," and to "encourage member countries to establish the strategy and action plans about sustainable energy development, in order to promote sustainable energy investment and hugely increase the proportion of sustainable energy in the global energy structure." 14

The recent decades have witnessed dramatic changes in the global energy landscape, and future development of global energy governance is confronted with more complicated situations due to socioeconomic and environment tradeoffs. The international community, G20 members in particular, should work together under the Paris Agreement on climate change and the UN 2030 Agenda for Sustainable Development. For better solutions to global energy issues require the commitments and contributions from all relevant stakeholders - not only governmental actors and inter-governmental organizations, but also private sectors.

With the Paris Agreement having come into effect, the focus of implementing the Agreement in 2017 has shifted to how the Nationally Determined Contributions (NDCs) that set out each country's goals can be realized by green development. However, there remains a huge gap between the goal of keeping the rise of global temperature below 2 degrees centigrade above pre-industrial levels and the final outcome of the NDCs by the "bottom-up approach" of climate governance. Moreover, the major problem of climate change is rooted in the energy consumption structure. If G20 members fail to decouple their heavy dependence on fossil fuel and reduce subsidies for traditional energy, then it is almost hopeless for

\section{President Trump's} climate policy creates both challenges and opportunities for the G20 to lead in global energy governance. the world to pursue sustainable economic growth.

Other than structural obstacles, global energy governance is also facing new challenges from the change of leadership in several major countries, especially the United States. The Trump administration is now moving the United States away from its commitment to the Paris Agreement and

${ }^{14}$ Ibid. 
domestic energy regulations embodied in the Clean Power Plan. It has also taken actions to reduce the subsidy for renewable energy, support the use of fossil fuel energy, and is trying to realize the absolute energy independence of the United States. Instead of promoting clean energy and international cooperation emphasized by the G20, President Trump obviously favors traditional energy such as oil, gas and coal. To him, clean energy - both renewable energy and nuclear energy - does not deserve much support, as it will not generate immediate economic gains or many job opportunities. This non-cooperative position of the United States certainly calls for new leadership in global energy governance, which can be created through the collective efforts of other G20 members.

In practice, G20 members should strive for the support of other UN member states as well as related international organizations and other stakeholders on the principles of consensus, inclusiveness and integration, in order to promote the G20 to become a chief coordinating platform for global energy affairs. The G20 should set up a permanent energy network with a permanent secretariat, preferably located in Asia. Discussion should be encouraged among Energy Ministers of G20 member countries to advance their common principles on energy. All major actors in the energy sphere, including governments, corporations and other market actors, should be invited to join such a network. Besides, the G20 should create suitable forums to facilitate cooperation and dialogue on renewable energy, energy efficiency and energy trade.

\section{China's Approach to Global Energy Governance}

The G20's role in global energy governance is of great significance to China's energy security. In the coming five to ten years, the Chinese economy will gradually step into the post-industrialization phase. Energy has been a critical factor in facilitating China's sustainable development. In 2025, China will constitute about one-third of the world's oil imports. Faced by both domestic and international energy constraints, energy security will increasingly become a serious issue for China. Although there remains a conflict between the international energy system led by Western countries and the increasing demand from China, China has in general benefited from the availability and stability of its energy imports over the past three decades. The existing international system guarantees that China enjoys a 
stable energy supply chain. With relatively stable oil prices and an ever stronger buyers' market, China is gaining more leverage in negotiations as the biggest market for energy trade. Having increased its share in global oil imports from 6 percent in 2005 to 15 percent in 2014, China has become the top oil-importing country in the world.

\section{China should tap on the G20 platform to advance domestic and international energy transition.}

The G20 provides China with a good opportunity to enhance its role in global energy governance. For now, OECD countries take up 63 percent of global oil consumption, EU countries 18 percent and the Asia-Pacific Economic Cooperation (APEC) countries 54.5 percent. Compared with the United States and Japan, both being members of the OECD, the IEA and the APEC, China is a late-comer to the game, thus it does not have much say in global oil affairs. However, with the continuing rise of emerging economies, China should participate more actively in global energy governance via suitable platforms like the G20.

In 2012, then Chinese Premier Wen Jiabao proposed integrating issues of global energy governance into the G20 agenda. For participation in global governance through the G20 would accustom China to the rules and operations of the international energy system, so that China could rapidly learn to strike a balance between energy cooperation with other economies and its own national interest. In other words, it was up to China to explore the common ground between its energy security needs and the demand of the international community for public goods in global energy. By tapping into those global institutions for energy governance, China would be in a position to foster a favorable international environment for its own energy security.

Indeed, despite various internal conflicts among Western economies, they share much common interest in maintaining their political, financial, technological, and other advantages over developing countries, as well as in holding back the rapid rise of emerging economies. As the biggest developing nation and second largest economy of the world, China should seek greater leadership in global energy governance and champion the trend of low-carbon development. Rather than topple the existing international energy power structure, China should try to improve its status in energy 
governance by increasing participation while upholding its national interest in the meantime.

The focus of the current global energy governance is on stimulating energy investment and sustainable development. Accordingly, China should seek to link its domestic low-carbon transformation initiative to similar global efforts, giving full support to the development of the clean energy sector. In addition, it should make more effort to join in global resource investment and promote the pattern of sustainable energy development, in order to fully exploit the global trend of green development.

At present, global energy governance by the United Nations tends to emphasize energy poverty elimination so as to guarantee billions of people's access to modern electricity service. The 7th UN sustainable development goal for 2030 mentions that, in order to make sure everyone can have affordable, reliable and sustainable modern energy, international cooperation must be strengthened to promote research of clean energy, to construct more infrastructure, and to stimulate more advanced exploitation technology. To enhance South-South collaboration and bolster its international status, China should make active contribution to this collective effort. Within the South-South framework, China should increase its engagement in communication and cooperation with other developing economies for better energy security, for it helps relieve the concerns of energy producers with regard to China's overseas investment and huge resource imports. Meanwhile, as China sends its representatives to various coordinating mechanisms of resource-rich countries, such as the OPEC and the Gas Exporting Countries Forum, its participation is very conducive to the efficiency of those mechanisms, thus beneficial to global energy governance in the long run. 